\title{
Productivity and Composition of Fatty Acids in Chicks fed with Azadirachta indica A. Juss
}

\author{
Productividad y composición de ácidos grasos en pollos \\ alimentados con Azadirachta indica A. Juss
}

\author{
Imna Trigueros $\mathrm{V}_{1}{ }^{1,2} \mathrm{M} . \mathrm{Sc}$, Miguel Ramón $\mathrm{C},{ }^{1,2 *} \mathrm{M} . \mathrm{Sc}$, José Vázquez $\mathrm{O},{ }^{3} \mathrm{Ph} . \mathrm{D}$, \\ Juan Aguirre M,1,2 Ph.D, Carlos Garcia C,1,2 M.Sc, Jaime Martínez T,1,2 Ph.D.
}

\begin{abstract}
${ }^{1}$ Universidad Autónoma de Chiapas, Facultad de Ciencias Agrícolas, Campus IV, C.A. Ganadería Tropical Sustentable. Entronque Carretera Costera-Pueblo, Huehuetán, Chiapas, México, C.P. 30660. ${ }^{2}$ Maestría en Ciencias en Producción Agropecuaria Tropical, ${ }^{3}$ Universidad Autónoma de Chiapas. Centro de Biociencias, C.A. Biotecnología Avanzada, *Correspondence: miguelr00@hotmail.com
\end{abstract}

Received: June 2014; Accepted: January 2015.

\begin{abstract}
Objective. Evaluate the productivity and composition of fatty acids in chicks fed diets enriched with neem Azadirachta indica A. Juss seed flour. Materials and methods. 80 mixed broiler chicks of Arbor Acres stock and levels 0, 1, 3 and 5\% neem seed flour added to a commercial diet were evaluated. 20 experimental units were included in each treatment for five weeks. The consumption and weight gain were recorded, as well as the composition of fatty acids in the fat by means of alkaline transesterification. Data was statistically analyzed by a completely random procedure and the measurements were compared with the Tukey test $(p \leq 0.05)$. Results. The greatest weight gain, consumption and best feed conversion were found in the treatment that contains $1 \%$ neem seed flour. It also produced the increase in the proportion of polyunsaturated fatty acids, especially linoleic acid (C18:2 Omega-6) and eicosapentaenoic acid (C20:5 omega-3), and the proportion of palmitic acid (C16:0). The consumption of feed diminished when $5 \%$ of neem flour was added. Conclusions. It was demonstrated that incorporating $1 \%$ neem seed flour in the diet of broiler chicks modifies the consumption of fatty acids without harming its productive behavior.
\end{abstract}

Key Words: Consumption, weight gain, neem (Source: $C A B$ ).

\section{RESUMEN}

Objetivo. Evaluar la productividad y composición de ácidos grasos en pollos alimentados con dietas adicionadas con harina de semilla de neem Azadirachta indica A. Juss. Materiales y métodos. Se emplearon 80 pollos mixtos de la estirpe Arbor Acres de engorda y se evaluaron los niveles 0, 1, 3 y $5 \%$ de harina de semilla de neem añadidos a una dieta comercial. En cada tratamiento se tuvieron 20 unidades experimentales con una duración de cinco semanas. Se registró el consumo y la ganancia de peso, así como la composición de los ácidos grasos de la grasa mediante transesterificación alcalina. Los datos se analizaron estadísticamente por el procedimiento completamente al azar y las medias se compararon con la prueba de Tukey $(p \leq 0.05)$. Resultados. La mayor ganancia de peso, consumo y la mejor conversión alimenticia correspondió al tratamiento que contenia $1 \%$ de harina de semilla de 
neem. También propició el aumento en la proporción de ácidos grasos poliinsaturados especialmente en el ácido linoleico, (C18:2 omega-6) y en el ácido eicosapentaenoico (C20:5 omega-3), y de manera concomitante se redujo la proporción del ácido palmítico (C16:0). El consumo de alimento disminuyó al adicionar $5 \%$ de harina de neem. Conclusiones. Se demostró que la incorporación de $1 \%$ de harina de semilla de neem en la dieta de los pollos de engorda modifica la composición de ácidos grasos sin perjudicar su comportamiento productivo.

Palabras clave: Consumo, ganancia de peso, neem (Fuente: $C A B$ ).

\section{INTRODUCTION}

Poultry farming produces protein at a lower cost in comparison with products of a similar origin. The demand for quality protein for the population has driven the study and exploitation of different plant species that could favor an increase in poultry breeding (1) with additional benefits for the consumer, such as a greater proportion of unsaturated or polyunsaturated acids, and higher quality protein in chicken meat (2). Some of these characteristics have been developed by feeding poultry with vegetable products, such as seeds and fruits, which contain unsaturated fatty acids (3). Consequently, the production and commercializing of poultry meat with a lesser proportion of fats and saturated fatty acids, as well as increasing the omega- 3 polyunsaturated acids, is highly desirable as a nutritional element to prevent cardiovascular diseases or inflammatory pathologies (4-6). In this sense, neem Azadirachta indica $A$. Juss has been considered, a species that belongs to the Meliaceae family and that is highly adaptable in tropical and subtropical regions (7), as a potential for poultry feed, by considering that the seeds contain considerable amounts of unsaturated and polyunsaturated fatty acids and proteins. However, neem seeds also contain high amounts of raw fiber as well as some triterpenoid compounds that could seriously limit its consumption (8). Due to the above, the general objective was to evaluate the productivity and composition of fatty acids in the fat of chickens fed different compositions of neem Azadirachta indica A. Juss seed flour.

\section{MATERIALS AND METHODS}

Study site and stages. This study was developed in two stages; one in the field for the weight, consumption and feed conversion variables (FC) of the birds, and the other in the laboratory to determine in each treatment the profile of fatty acids in the chickens fed. The first stage was done in the poultry module of the Faculty of Agricultural Sciences (FCA) Campus IV, of the Universidad Autónoma de Chiapas,

\section{INTRODUCCIÓN}

La avicultura proporciona proteína a menor costo en comparación con productos de origen similar. La demanda de proteína de calidad por la población ha impulsado el estudio y la explotación de diferentes especies de plantas que podrían favorecer un aumento en la producción avícola (1) con beneficios adicionales para el consumidor, tales como una mayor proporción de ácidos insaturados o poliinsaturados, y proteína de mayor calidad en la carne de pollo (2). Algunas de estas características se han desarrollado alimentando a las aves con productos de origen vegetal, como semillas y frutas, que contienen ácidos grasos insaturados (3). En consecuencia, la producción y comercialización de carne de ave con menor proporción de grasa y ácidos grasos saturados, así como el incremento de ácidos poliinsaturados omega-3, es altamente deseable como elemento nutricional para la prevención de enfermedades cardiovasculares o patologías inflamatorias (4-6). En ese sentido, se ha considerado a neem Azadirachta indica A. Juss., especie perteneciente a la familia Meliaceae y de amplia adaptación en las regiones tropicales y subtropicales (7), como especie potencial para la alimentación avícola, al considerar que contiene en sus semillas cantidades considerables de ácidos grasos insaturados, poliinsaturados y de proteínas. Sin embargo, la semilla de neem contiene alto contenido de fibra cruda así como algunos compuestos triterpenoides que pueden limitar seriamente su consumo (8). Por lo anterior el objetivo general fue evaluar la productividad y composición de ácidos grasos en la grasa de los pollos alimentados a diferentes concentraciones de harina de semilla de neem Azadirachta indica A. Juss.

\section{MATERIALES Y MÉTODOS}

Sitio y etapas del estudio. El presente estudio se desarrolló en dos etapas; una de campo para las variables peso, consumo y conversión alimenticia (CA) de las aves, y otra de laboratorio para determinar en cada tratamiento el perfil de acidos grasos en los pollos alimentados. La 
municipality of Huehuetán, Chiapas, Mexico, located at parallel $14^{\circ} 59^{\prime} 50^{\prime \prime} \mathrm{N}$ and meridian $92^{\circ} 24^{\prime} 0^{\prime \prime}$ west of Greenwich. The region's climate is subhumid tropical with summer rains $(\mathrm{Am})$. The second stage was carried out in the research laboratory of the Center of BioSciences of the Universidad Autónoma de Chiapas, city of Tapachula de Córdova y Ordoñez, Chiapas, located at $14^{\circ} 53^{\prime} 36.31^{\prime \prime} \mathrm{N}$ and $92^{\circ} 16^{\prime} 22.83^{\prime \prime} \mathrm{W}$ and 147 meters above sea level.

Birds and diet preparation. 80 commercial chicks of the Arbor stock, one day old, were randomly distributed in four groups of 20 chicks and each group was placed in a $6 \mathrm{~m}^{2}$ space. Neem seeds were obtained from trees that were 20 years old that had grown in the FCA. The fruit was collected in autumn and were deposited in water for $24 \mathrm{~h}$. After this time, the mesocarp was manually removed to separate the seed, which was washed and sun-dried for a week, and was later put in a forced air oven (Sheldon, VWR $1390 \mathrm{FM}, \mathrm{USA}$ ) at $70^{\circ} \mathrm{C}$ for $24 \mathrm{~h}$ to reduce the humidity to $12 \%$. The dried seeds were ground and sifted to obtain flour with particle sizes between 1 and $2 \mathrm{~mm}$, and it was incorporated and mixed manually in the commercial diets each week, according to the corresponding percentage of the treatment (Table 1 ).

Table 1. Proximal composition of experimental diets depending on the inclusion of neem Azadirachta indica A. Juss seed flour

\begin{tabular}{lcccc}
\hline \multirow{2}{*}{ Parameter } & \multirow{2}{*}{ CACI } & \multicolumn{3}{c}{ Percentage of neem seed flour } \\
\cline { 3 - 5 } & & $\mathbf{1 \%}$ & $\mathbf{3 \%}$ & $\mathbf{5 \%}$ \\
\hline Humidity (\%) & 12.0 & $9.03 \pm 0.08$ & $8.45 \pm 0.05$ & $7.63 \pm 0.10$ \\
Protein (\%) & 17.0 & $14.97 \pm 1.37$ & $17.55 \pm 1.65$ & $16.96 \pm 0.16$ \\
Raw fiber \% & 5.0 & $4.32 \pm 0.01$ & $10.55 \pm 0.21$ & $13.30 \pm 0.85$ \\
Fat (\%) & 3.0 & $7.67 \pm 1.59$ & $5.30 \pm 0.30$ & $7.1 \pm 1.05$ \\
Ashes (\%) & 8.0 & $9.24 \pm 0.29$ & $8.72 \pm 0.32$ & $8.49 \pm 0.02$ \\
ELN (by difference) & 55.0 & 54.77 & 49.43 & 46.52 \\
EM Kcal/kg & Nc & 1069.30 & 962.41 & 1086.07 \\
\hline
\end{tabular}

CACI: Composition of commercial starter feed

Nc: Not calculated. The values are the mean of three repetitions \pm standard error.

During the first eight days of the study, all the chicks were only given commercial feed, early stage. From day nine until day 23 the chicks were given diets with the respective treatments using early stage feed base. From day 23 to the end of the study (day 35), the early stage feed was substituted for the neem flour that corresponded to each treatment. The chicks were fed ad libitum.

Treatments and feeding. The treatments were: 1) control that consumed only commercial feed (CF), 2) CF plus1\% neem seed flour (NSF), 3) primera etapa se realizó en el modulo avícola de la Facultad de Ciencias Agrícolas (FCA) Campus IV, de la Universidad Autónoma de Chiapas, municipio de Huehuetán, Chiapas, México, ubicada geográficamente en el paralelo $14^{\circ} 59^{\prime} 50^{\prime \prime}$ latitud N y el meridiano $92^{\circ} 24^{\prime} 0^{\prime \prime}$ longitud Oeste de Greenwich. El clima de la región pertenece al tropical subhúmedo con lluvias en verano (Am). La segunda etapa se llevó a cabo en el laboratorio de Investigación del Centro de Biociencias de la Universidad Autónoma de Chiapas, ciudad de Tapachula de Córdova y Ordoñez, Chiapas, ubicado en las coordenadas geográficas $14^{\circ} 53^{\prime} 36.31^{\prime \prime} \mathrm{N}$ y $92^{\circ} 16^{\prime} 22.83^{\prime \prime} \mathrm{O}$ y $147 \mathrm{msnm}$.

Aves y preparación de dietas. Se utilizaron 80 pollos comerciales de la estirpe Arbor de un día de edad, distribuidos aleatoriamente en cuatro grupos de 20 pollos y cada grupo colocado en un espacio de $6 \mathrm{~m}^{2}$. Las semillas de neem se obtuvieron de los árboles de 20 años de edad que han crecido en la FCA. Se recolectaron los frutos en los meses de otoño y se depositaron en agua por $24 \mathrm{~h}$. Después de este tiempo, se retiró manualmente el mesocarpio hasta separar la semilla, la cual fue lavada y secada al sol durante una semana, y posteriormente se introdujeron en estufa de aire forzado (Sheldon, VWR 1390FM, USA) a $70^{\circ} \mathrm{C}$ durante $24 \mathrm{~h}$ para reducir la humedad hasta $12 \%$. Las semillas secas fueron molidas y tamizadas para obtener la harina con tamaño de partícula entre 1 y $2 \mathrm{~mm}$, y la misma fue incorporada y mezclada manualmente en las dietas comerciales cada semana, de acuerdo con el porcentaje correspondiente del tratamiento (Tabla 1).

Durante los primeros ocho días del estudio, a todos los pollos se les proporcionó solamente alimento comercial etapa iniciador. A partir del día nueve, y hasta el día 23, a los pollos se les suministraron las dietas de los respectivos tratamientos empleando como base alimento iniciador. Del día 23 y hasta el final del estudio (35 d), se sustituyó el alimento iniciador por finalizador más la harina de neem que correspondió a cada tratamiento. Los pollos fueron alimentados ad libitum.

Tratamientos y alimentación. Los tratamientos fueron: 1) Testigo consumiendo sólo el alimento comercial $(A C), 2$ ) AC más $1 \%$ de harina de semilla de neem (HSN), 3) AC más $3 \%$ de HSN y 4) AC más $5 \%$ con HSN. Se utilizó un diseño completamente al azar con 4 repeticiones y cada repetición estuvo integrada por 20 pollos en cada uno de los tratamientos. 
CF plus 3\% NSF and 4) CF plus 5\% with NSF. A completely ramdomized design was used with four repetitions, and each repetition integrated 20 chicks in each treatment.

Productive parameters. The weekly body weight of each bird was recorded weekly, and the daily consumption of feed and CF was calculated by the amount of feed rejected by the group.

Composition of fatty acids. Fat was obtained by means of the Soxhlet method (9), and the fatty acid methyl ester (FAMEs) were obtained by means of alkaline transesterification (10). The procedure was started by depositing in a vial (washed with hexane and dried for $2 \mathrm{~h}$ at $300^{\circ} \mathrm{C}$ ) $2 \mathrm{ml}$ of hexane and $40 \mathrm{mg}$ of abdominal fat at $40^{\circ} \mathrm{C}$ for $1 \mathrm{~min}$, and after this time, $100 \mu \mathrm{l}$ of sodium methoxide were added (prepared with $\mathrm{NaOH} 2 \mathrm{M}$ in absolute methane), was shaken vigorously for 2 min, was heated for $5 \mathrm{~min}\left(40^{\circ} \mathrm{C}\right)$ and was centrifuged at $5000 \mathrm{rpm}$ for $10 \mathrm{~min}$. The supernatant containing the FAMEs was used to determine the composition of fatty acids by gas chromatography mass spectrometry (Thermo Scientific Focus GC chromatograph and Thermo Scientific DSQ II spectrometer of mass).

$1 \mu \mathrm{l}$ of the FAMEs was injected in a column of intermediate polarity with the following temperature program: $100^{\circ} \mathrm{C}$, heated $25^{\circ} \mathrm{C} \mathrm{min}^{-1}$ to $200^{\circ} \mathrm{C}, 2.5^{\circ} \mathrm{C} \mathrm{min} \mathrm{m}^{-1}$ to $230^{\circ} \mathrm{C}$ for $1 \mathrm{~min}$, and $10^{\circ} \mathrm{C} \mathrm{min}^{-1}$ to $250^{\circ} \mathrm{C}$. The chromatograph was operated with helium gas, creating a pressure of $3.5 \mathrm{psi}$. The injector was programmed in Split 60:1 mode at a temperature of $280^{\circ} \mathrm{C}$. The spectrometer of masses was operated with ionization voltage of $70 \mathrm{eV}$, and interface temperature of $280^{\circ} \mathrm{C}$ in Scan and mass range from 50 a $500 \mathrm{~m} \mathrm{z}^{-1}$. The compounds of each sample were identified by comparison with it mass spectrum with the compounds of the library of the National institute of Standards and Technology (NIST). The sum of all the proportions of fatty acids was considered $100 \%$ of the fat and the proportion of each fatty acid was reported as a relative percentage. Four repetitions of each treatment were analyzed.

Statistical analysis. Data were statistically analyzed by means of the SAS program version 8.2 , and the comparisons between treatment means by Tukey $(p \leq 0.05)(11)$.

\section{RESULTS}

Productive parameters. Greater weight at sacrificing was seen in chicks that consumed the diet with the least percentage of NSF
Parámetros productivos. Se registró semanalmente el peso corporal de cada ave, y el consumo diario de alimento y la CA se calculó con la cantidad de alimento rechazado por el grupo.

Composición de ácidos grasos. Se obtuvo la grasa mediante el método de Soxhlet (9), y se procedió a obtener los esteres metílicos de ácidos grasos (FAMEs), mediante transesterificación alcalina (10). El procedimiento inició depositando en un vial (lavado con hexano y secado por $2 \mathrm{~h}$ a $300^{\circ} \mathrm{C}$ ) $2 \mathrm{ml}$ de hexano y $40 \mathrm{mg}$ de grasa abdominal a $40^{\circ} \mathrm{C}$ por $1 \mathrm{~min}, \mathrm{y}$ después de éste tiempo, se agregaron $100 \mu \mathrm{l}$ de metóxido de sodio (preparado con $\mathrm{NaOH} 2 \mathrm{M}$ en metanol absoluto), se agitó vigorosamente por $2 \mathrm{~min}$, se calentó por $5 \mathrm{~min}\left(40^{\circ} \mathrm{C}\right)$ y fue centrifugado a $5000 \mathrm{rpm}$ por $10 \mathrm{~min}$. El sobrenadante conteniendo los FAMEs se empleó para determinar la composición de ácidos grasos por cromatografía de gases-espectrometría de masas (cromatógrafo Thermo Scientific Focus GC y espectrómetro de masas Thermo Scientific DSQ II).

Se inyectó $1 \mu$ de los FAMEs en una columna de polaridad intermedia con el siguiente programa de temperaturas: $100^{\circ} \mathrm{C}$, calentamiento $25^{\circ} \mathrm{C}$ $\mathrm{min}^{-1}$ hasta $200^{\circ} \mathrm{C}, 2.5^{\circ} \mathrm{C} \mathrm{min}^{-1}$ hasta $230^{\circ} \mathrm{C}$ por

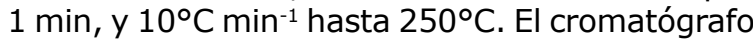
se operó con helio como gas acarreador a una presión de 3.5 psi. El inyector se programó en modo Split $60: 1$ a una temperatura de $280^{\circ} \mathrm{C}$. El espectrómetro de masas se operó con voltaje de ionización de 70 eV, y temperatura de interface de $280^{\circ} \mathrm{C}$ en modo Scan y rango de masas de 50 a $500 \mathrm{~m} \mathrm{z}^{-1}$. Los compuestos de cada muestra se identificaron por comparación de su espectro de masas con los compuestos de la biblioteca del Instituto Nacional de Estándares y Tecnología (NIST). Se consideró la suma de todas las proporciones de ácidos grasos como el $100 \%$ de la grasa y se reportó la proporción de cada ácido graso como porcentaje relativo. Se analizaron cuatro repeticiones por tratamiento.

Análisis estadístico. Los datos se analizaron estadísticamente por medio del programa SAS ver 8.2 , y las comparaciones entre medias de tratamientos por Tukey $(\mathrm{p} \leq 0.05)(11)$.

\section{RESULTADOS}

Parámetros productivos. El mayor peso al sacrificio se presentó en los pollos que consumieron la dieta con menor porcentaje de HSN (1\%) y en el tratamiento testigo ( $p \leq 0.05)$. El menor peso corporal se observó en los pollos que consumieron $5 \%$ de HSN (Tabla 2). El aumento en el porcentaje 
$(1 \%)$ and the constant treatment $(p \leq 0.05)$. The lowest body weight was observed in the chicks that consumed $5 \%$ of NSF (Table 2). The increase in the percentage of NSF in the diet induced a lower body weight in the birds. When 5\% NSF was added to commercial feed, the final weight of the birds was $10.2 \%$ less in comparison with birds fed with $1 \%$ neem seed and $5.9 \%$ less weight in comparison with chicks fed with only commercial feed.

The birds' consumption of feed was restricted by the increase in the NSF percentages. The greater consumption was presented in the treatment where the birds consumed the lesser proportion of NSF. The differences in consumption between the groups were statistically different $(p \leq 0.05)$. In the case of the treatment with $1 \% \mathrm{NSF}$ the consumption diminished only $0.6 \%$ and as the NSF was increased to 3 , the consumption diminished by $2 \%$ and when it was at $5 \%$ the same was reduced to $2.6 \%$ in relation to the consumption of the birds that only consumed CF.

In the case of $\mathrm{CF}$ the tendencies of inclusion of the different percentages of NSF in the commercial diet was contrary to the consumption; that is, the lower percentage ( $1 \%$ of NSF) presented the lesser CF and this value increased as the NSF percentage increased.

Composition of fatty acids. The composition of fatty acids found in the abdominal fat of chicks treated in this study is presented in table 3. By increasing the concentration of NSF the saturated fatty acids were significantly diminished.

The saturated fatty acids in the $\mathrm{C} 16: 0$ series, of which palmitoleic and palmitic acid presented the largest proportion in a control group, that is, in the birds fed only with commercial feed, in comparison with the treatments that included

Table 2. Productive parameters of broiler chicks fed with different percentages of neem seed flour.

\begin{tabular}{|c|c|c|c|}
\hline Treatment & $\begin{array}{l}\text { Final weight } \\
\left(\text { g.ave }^{-1}\right)\end{array}$ & $\begin{array}{c}\text { Feed } \\
\text { consumption } \\
(\text { g.bird.week } \\
\text {-1) }\end{array}$ & $\begin{array}{c}\text { Feed } \\
\text { conversion }\end{array}$ \\
\hline$A C$ & $\begin{array}{c}2208.33 \mathrm{ab} \\
\pm 31.8\end{array}$ & 1666 a** & $\begin{array}{l}1.83 \mathrm{~b} \\
\pm 0.05\end{array}$ \\
\hline $1 \%$ NSF plus CF & $\begin{array}{l}2312.94 \mathrm{a} \\
\quad \pm 42.6\end{array}$ & 1657 a & $\begin{array}{l}1.75 a \\
\pm 0.07\end{array}$ \\
\hline $3 \%$ NSF plus CF & $\begin{array}{c}2123.83 b c \\
\pm 17.3\end{array}$ & $1635 \mathrm{~b}$ & $\begin{array}{c}1.87 b c \\
0.04\end{array}$ \\
\hline $\begin{array}{l}5 \% \text { NSF flour plus } \\
\text { CF }\end{array}$ & $\begin{array}{c}2076.11 \mathrm{C} \\
\pm 29.3\end{array}$ & $1623 \mathrm{c}$ & $\begin{array}{l}1.94 \mathrm{c} \\
0.05\end{array}$ \\
\hline
\end{tabular}

* Values with different letters within each factor and column are statistically different $(p \leq 0.05)$.

** The value indicates the rejection of the feed by the group of 20 chicks per treatment.

de HSN en la dieta indujo menor peso corporal de las aves. Cuando se adicionó $5 \%$ de la HSN al alimento comercial, el peso final de las aves fue $10.2 \%$ menor en comparación a los pollos alimentados con el $1 \%$ de la harina de neem y $5.9 \%$ menor peso en comparación a los pollos alimentados solo con el alimento comercial.

El consumo de alimento de las aves fue restringido por el aumento en los porcentajes de HSN. El mayor consumo se presentó en el tratamiento donde las aves consumieron la menor proporción de HSN. Las diferencias en el consumo entre los grupos fueron estadísticamente diferentes $(p \leq 0.05)$. En el caso del tratamiento con $1 \%$ de HSN el consumo disminuyó solamente $0.6 \%$ y conforme se incrementó a $3 \mathrm{HSN}$, el consumo disminuyó $2 \%$ y cuando fue del $5 \%$ el mismo se redujo a $2.6 \%$ en relación al consumo de las aves que sólo consumieron AC.

En el caso de la CA las tendencias de la inclusión de los diferentes porcentajes de HSN en la dieta comercial fue contraria al consumo; es decir, el porcentaje más bajo (de $1 \%$ de HSN), presentó la menor CA y se incrementó este valor, conforme aumentó el porcentaje HSN.

Composición de ácidos grasos. En la tabla 3, se presenta la composición de ácidos grasos encontrados en la grasa abdominal de los pollos tratados en este estudio. Al aumentar la concentración de HSN disminuyeron significativamente los ácidos grasos saturados.

Table 3. Percentage relative to the composition of the principal fatty acids contained in abdominal fat in broiler chicks fed with different concentrations of neem seed flour.

\begin{tabular}{|c|c|c|c|c|c|}
\hline \multirow[t]{2}{*}{ Fatty acid } & \multirow{2}{*}{$\begin{array}{c}\text { Commercial } \\
\text { Feed }\end{array}$} & \multicolumn{3}{|c|}{$\begin{array}{l}\text { Percentage of neem seed flour } \\
\text { in commercial feed }\end{array}$} & \multirow[t]{2}{*}{ CV } \\
\hline & & $1 \%$ & $3 \%$ & $5 \%$ & \\
\hline C14:0 Myristic & $\begin{array}{c}0.46^{*} \\
\pm 0.025 b\end{array}$ & $\begin{array}{c}0.56 \\
\pm 0.0017 a\end{array}$ & $\begin{array}{c}0.54 \\
\pm 0.0151 \mathrm{ab}\end{array}$ & $\begin{array}{c}0.51 \\
\pm 0.0004 a b\end{array}$ & 3.9 \\
\hline C16:1 Palmitoic & $\begin{array}{l}5.64 \\
\pm 0.013 a\end{array}$ & $\begin{array}{l}4.80 \\
\pm 0.157 \mathrm{~b}\end{array}$ & $\begin{array}{ll} & 4.86 \\
\pm & 0.011 b\end{array}$ & $\begin{array}{l}4.61 \\
\pm 0.071 b\end{array}$ & 2.4 \\
\hline C16:0 Palmitic & $\begin{array}{c}22.28 \\
\pm 0.167 a\end{array}$ & $\begin{array}{c}21.31 \\
\pm 0.372 \mathrm{ab}\end{array}$ & $\begin{array}{c}20.83 \\
\pm 0.212 \mathrm{ab}\end{array}$ & $\begin{array}{l}20.10 \\
\pm 0.245 b\end{array}$ & 1.7 \\
\hline C18:0 Stearic & $\begin{array}{c}5.77 \\
\pm 0.019 \mathrm{bc}\end{array}$ & $\begin{array}{c}6.08 \\
\pm 0.029 a\end{array}$ & $\begin{array}{c}5.86 \\
\pm 0.024 b\end{array}$ & $\begin{array}{l}5.71 \\
\pm 0.005 c\end{array}$ & 0.5 \\
\hline 18:1n-9 Oleic & $\begin{aligned} & 44.62 \\
\pm & 0.340 \mathrm{a}\end{aligned}$ & $\begin{array}{c}44.43 \\
\pm 0.017 \mathrm{a}\end{array}$ & $\begin{array}{c}44.14 \\
\pm 0.718 \mathrm{a}\end{array}$ & $\begin{array}{l}43.55 \\
\pm 0.554 a\end{array}$ & 1.5 \\
\hline 18:3n-3 Linolenic & $=\begin{array}{c}0.14 \\
\pm 0.004 a\end{array}$ & $\begin{array}{c}0.15 \\
\pm 0.021 \mathrm{a}\end{array}$ & $\begin{array}{c}0.16 \\
\pm 0.011 \mathrm{a}\end{array}$ & $\begin{array}{c}0.18 \\
\pm 0.009 a\end{array}$ & 12.8 \\
\hline 18:2n-6 Linoleic & $\begin{aligned} & 20.25 \\
\pm & 0.481 \mathrm{~b}\end{aligned}$ & $\begin{array}{c}21.16 \\
\pm 0.104 \mathrm{ab}\end{array}$ & $\begin{array}{c}22.22 \\
\pm 0.474 \mathrm{ab}\end{array}$ & $\begin{array}{c}24.02 \\
\pm 0.869 a\end{array}$ & 3.5 \\
\hline$C 20: 5 n-3$ EPA & $\begin{array}{l}0.055 \\
\pm 0.001 \mathrm{c}\end{array}$ & $\begin{aligned} & 0.29 \\
\pm & 0.028 \mathrm{a}\end{aligned}$ & $\begin{array}{c}0.21 \\
\pm 0.001 \mathrm{ab}\end{array}$ & $\begin{array}{c}0.16 \\
\pm 0.006 \mathrm{~b}\end{array}$ & 10.9 \\
\hline $\begin{array}{l}\text { C20:4n-6 } \\
\text { Arachidonic }\end{array}$ & $\begin{array}{c}0.11 \\
\pm 0.006 \mathrm{a}\end{array}$ & $\begin{array}{c}0.07 \\
\pm 0.0004 a\end{array}$ & $\begin{array}{l}0.06 \\
\pm 0.0005 \mathrm{a}\end{array}$ & $\begin{array}{c}0.19 \\
\pm 0.0060 \mathrm{a}\end{array}$ & 10.4 \\
\hline $\begin{array}{l}C 20: 3 n-6 \\
\text { Dihomo and } \\
\text { linolenic }\end{array}$ & $\begin{array}{c}0.15 \\
\pm 0.0022 a\end{array}$ & $\begin{array}{c}0.13 \\
\pm 0.0018 \mathrm{~b}\end{array}$ & $\begin{array}{c}0.14 \\
\pm 0.0055 b\end{array}$ & $\begin{array}{c}0.10 \\
\pm 0.0051 \mathrm{c}\end{array}$ & 4.6 \\
\hline
\end{tabular}


some percentage of NSF in the diet. The results were statistically different $(p \leq 0.05)$. Stearic acid was increased with the $1 \%$ NSF in the diet and was statistically different from the other treatments $(p \leq 0.05)$. Oleic acid presented similar percentages among the treatments and without statistical differences $(p \geq 0.05)$ between them. The concentrations of polyunsaturated linoleic acids were increased as the percentages of NSF were increased in the diet. Linoleic acid, with a diet of $1 \%$, increased $4.4 \%, 9.7 \%$ with $3 \%$ and $18.6 \%$ with the $5 \%$ dose in relation to the birds that consumed only commercial feed and were statistically different $(p \leq 0.05)$. The differences found in linolenic acid by adding 1, 3 and $5 \%$ de NSF to the commercial diet were 7.1, 14.2 and $28.5 \%$ in relation to the commercial diet and without differences $(p \geq 0.05)$ between the treatments. Instead of eicosapentaenoic acid was found in greater proportion with the lesser quantity of NSF added to the commercial diet. This represents the greater increase between the fatty acids evaluated. The arachidonic acid did not show an increasing tendency with the NSF levels in the diet, only with a greater percentage, the increase of it was the highest, but without significant differences between them.

The control, with no added NSF, presented a lesser content of fatty Omega- 6 acids with $20.90 \%(p \geq 0.05)$ respecting 1,3 and $5 \%$ with $21.47,21.96$ and $23.30 \%$ respectively (Table 3 ). As far as the relationship of omega- 6 and omega-3 fatty acids, significant differences were not seen $(p \geq 0.05)$ in any of the four treatments (Table 3 ).

\section{DISCUSSION}

The final weight of the birds fed with NSF was different in the percentages added to the commercial diet. Adding 1\% NSF increased the final weight of the chicks. The differences in weight of the birds, with their different percentages of NSF, can be influenced by the decrease in the consumption, caused by the increase of the raw fiber content with the addition of the percentages 3 and $5 \%$ of flour, at the same time that the greater percentage of NSF restricted consumption and consequently the final weight decreased. The decrease in consumption of the feed with high fiber content for the birds has been consigned $(12,13)$. Additionally, the fiber content, another factor that could have restricted the consumption in the different diets is the presence of polyfenols, triglycerides and some triterpenoid compounds
Los ácidos grasos saturados de la serie $\mathrm{C} 16: 0$, del cual el ácido palmitoleico y palmítico presentaron mayor proporción en el grupo testigo, es decir, en las aves alimentadas solo con alimento comercial, en comparación con los tratamientos que incluyeron algún porcentaje de HSN en la dieta. Los resultados fueron diferentes estadísticamente $(p \leq 0.05)$. El ácido estéarico se incrementó con el porcentaje de $1 \%$ de HSN en la dieta y fue estadísticamente diferente a los otros tratamientos $(p \leq 0.05)$. El ácido oleico presentó porcentajes semejantes entre tratamientos y sin diferencias estadísticas $(p \geq 0.05)$ entre ellos. Se incrementaron las concentraciones de ácidos poliinsaturados linoleico, conforme aumentaron los porcentajes de HSN en la dieta. El ácido linoleico, con la dieta de $1 \%$, aumentó $4.4 \%$, $9.7 \%$ con $3 \%$ y $18.6 \%$ con la dosis de $5 \%$ en relación a las aves que consumieron sólo alimento comercial y fueron estadísticamente diferentes $(p \leq 0.05)$. Las diferencias encontradas con el ácido linolénico al adicionar 1,3 y $5 \%$ de HSN a la dieta comercial, fueron de $7.1,14.2$ y $28.5 \%$ con relación a la dieta comercial y sin diferencia $(p \geq 0.05)$ entre tratamientos. En cambio el ácido eicosapentanoico se encontró en mayor proporción con la menor cantidad de HSN adicionada al alimento comercial. Esto representó el mayor incremento entre los ácidos grasos evaluados. El ácido araquidónico no registró tendencia ascendente con los niveles de HSN en la dieta, solamente, con el mayor porcentaje, el incremento del mismo fue el más alto, pero sin diferencias significativas entre ellos.

El testigo sin adición de HSN presentó el menor contenido de ácidos grasos omega- 6 con $20.90 \%$ $(p \geq 0.05)$ respecto a 1,3 y $5 \%$ con $21.47,21.96$ y $23.30 \%$ respectivamente (Tabla 3 ). En cuanto a la relación de ácidos grasos omega- 6 y omega-3 no se demostraron diferencias significativas $(p \geq 0.05)$ para ninguno de los cuatro tratamientos (Tabla 3 ).

\section{DISCUSIÓN}

El peso final de las aves alimentadas con la HSN fue diferente en los porcentajes adicionados a la dieta comercial. Adicionar $1 \%$ de HSN incrementó el peso final en los pollos. Las diferencias en el peso de las aves, con los diferentes porcentajes de HSN pueden estar influenciadas por la disminución en el consumo, ocasionado a su vez por el aumento en el contenido de fibra cruda con la adición de los porcentajes de 3 y $5 \%$ de harina, toda vez que a mayor porcentaje de HSN, se restringió su consumo y en consecuencia disminuyó su peso final. La disminución del consumo de alimento con alto contenido de fibra por las aves ha sido consignado $(12,13)$. Además, del contenido de fibra, otro factor que pudo haber restringido el consumo en las diferentes dietas es la presencia de polifenoles, 
in the neem, which determine the bitter taste that interferes in the sensorial perception of the birds (14). By increasing the percentages of fiber in the flour, the ingestion of feed diminishes (12), and therefore, lesser body weight is seen $(12,13)$ due to a reduction in the metabolizing the nutrients (12).

The lowest percentage of NSF in the conventional diet induced greater $\mathrm{CA}$, as well as consumption and weight gain. The final weight of the birds fed with NSF is greater in comparison with providing other components in the birds' diet $(15,16)$. The decreased concentration of saturated fatty acids in the fat of birds fed with NSF suggests benefits to the health of consumers (17).

Other authors (18) fed chicks with $10 \%$ pumpkin seed (Cucurbita moschata) and found that it diminished the abdomen and thigh fat in birds (19), added 33 and $66 \mathrm{~g}$ of pumpkin flour per $\mathrm{kg}$ of feed and they did not find significant differences in the variables of weight and feed conversion, but yes in the diminished abdominal fat in the birds. Broiler chicks with 5 and $10 \%$ chia flour (Salvia hispanica L.) found a greater content of linolenic acid and $a$ reduction in the content of palmitic acid in the tissue analyzed as the percentage of chia increased (20). Similarly, by adding $1 \%$ NSF produced an increase both in the proportion of linolenic acid (18:2 omega-6) and eicosapentaenoic (EPA: C20:5n-3). These results are greater when compared with the constant (without adding NSF).

In conclusion, the NSF of Azadirachta indica A. Juss., is a feed alternative for chicks and the greater weight and CA recorded when they consumed a diet that includes $1 \%$ NSF.

Adding $1 \%$ NSF increased the proportion of unsaturated fatty acids (linoleic) and polyunsaturated (eicosapentaeonic) and diminished the proportion of palmitic acid.

\section{Acknowledgments}

The authors would like to express their appreciation to the Center for Biosciences of the Universidad Autónoma de Chiapas and the National Council on Science and Technology (CONACYT) for their economic support to continue this investigation. trigliceridos y algunos compuestos triterpenoides en el neem, los cuales determinan el sabor amargo que interfieren en la percepción sensorial de las aves (14). Al aumentar los porcentajes fibra de la harina, disminuye la ingestión de alimento (12) y, por tanto, se tiene menor peso corporal $(12,13)$ por la disminución en la metabolización de los nutrientes (12).

El menor porcentaje de HSN en la dieta convencional indujo mayor CA, de igual forma para el consumo y la ganancia de peso. El peso final de las aves alimentadas con HSN es mayor en comparación con el suministro de otros componentes en las dietas de aves $(15,16)$. La disminución en la concentración de ácidos grasos saturados en la grasa de las aves alimentadas con HSN, sugiere beneficios a la salud de los consumidores (17).

Otros autores (18) alimentaron pollos con $10 \%$ de semilla de calabaza (Cucurbita moschata) y encontraron disminución de la grasa en abdomen y muslo de las aves (19) agregaron 33 y $66 \mathrm{~g}$ de harina de calabaza por $\mathrm{kg}$ de pienso y no encontraron diferencias significativas en las variables de peso y conversión alimenticia, pero sí, en la disminución de la grasa abdominal de las aves. En pollos de engorda con 5 y $10 \%$ de harina integral de chía (Salvia hispanica L.) se encontró mayor contenido de ácido linolénico y reducción en el contenido de ácido palmítico en los tejidos analizados a medida que se incrementó el porcentaje de chia (20). De manera similar, la adición del $1 \%$ de HSN propició aumento tanto en la proporción de ácido linolenico (18:2 omega-6) y eicosapentaenoico (EPA: C20:5 n-3). Estos resultados son mayores al ser comparados con el testigo (sin adicionarle HSN).

En conclusión la HSN de Azadirachta indica A. Juss., es una alternativa alimenticia para los pollos y el mayor peso y la CA se registró cuando consumieron la dieta con $1 \%$ de inclusión de HSN.

La adición de HSN en un 1\% propició el aumento en la proporción de ácidos grasos insaturados (linoleico) y poliinsaturados (eicosapentaenoico), y la disminución en la proporción del ácido palmítico.

\section{Agradecimientos}

Los autores quieren expresar sus agradecimientos al Centro de Biociencias, Universidad Autónoma de Chiapas $Y$ al Consejo Nacional de Ciencia y Tecnología (CONACyT) por el apoyo económico para continuar con esta investigación. 


\section{REFERENCIAS}

1. Odunsi AA, Adegbile SA, Akande TO, Olayeni TB. Neem (Azadirachta indica) Seed Cake in the Diets of Cockerel Chickens. Int J Poult Sci 2009; 8(1):47-51.

2. Cooper $S L$, Sinclair LA, Wilkinson RG, Hallett KG, Enser M, Wood JD, K. G. Hallett. Manipulation of the $n-3$ polyunsaturated fatty acid content of muscle and adipose tissue in lambs. J Anim Sci 2004; 82(5):1461-1470.

3. Girish K, Shankara Bhat S. Neem-A Green Treasure. Electr J Biol 2008; 4(3):102-111.

4. Din JN, Newby DE, Flapan AD. Omega 3 fatty acids and cardiovascular disease fishing for a natural treatment. BMJ 2004; 328(7430):30-35.

5. Kandasamy N, Franklin JF, Goenka N. The role of omega-3 fatty acids in cardiovascular disease, hypertriglyceridaemia and diabetes mellitus. $\mathrm{Br}$ J Diabetes Vasc Dis 2008; 8(3):121-126.

6. Ruxton CHS, Reed SC, Simpson MJA, $\mathrm{K}$. Millington, $\mathrm{KJ}$. The health benefits of omega-3 polyunsaturated fatty acids: a review of the evidence. J Hum Nutr Diet $2004 ; 17(5): 449-459$.

7. Ogbuewu IP, Odoemenam VU, Obikaonu HO, Opara MN, Emenalom OO, Uchegbu MV, Okoli IC, Esonu BO, Iloeje MU. The growing importance of neem (Azadirachta indica $A$. Juss) in Agriculture, Industry, Medicine and Environment: A review. Res ] Med Plant 2011; 5(3):230-245.

8. Uko OJ, Obaro AH, Kamalu TN. Studies on fatty acid composition and comparative response of broilers chicks to diet neem (Azadirachta indica) seed an palm oil. Niger Vet J 2008; 29(2):1-7.

9. A.O.A.C. Official Methods of Analysis of the Association of Official Agricultural Chemists. 16th Edition 3rd. revision. USA: Gaithersburg; 1997.

10. Ichihara K, Shibahara A, Yamamoto K, Nakayama T. An improved method for rapid analysis of the fatty acids of glycerolipids. Lipids 1996; 31(5):535-539.

11. Statistical Analysis Systems (SAS). 19992000. SAS/STAT user's Guide: SAS ${ }^{\circledR}$ versión 8.2 USA: SAS Institute Inc. Cary NC; 2000.
12. Uko OJ, Kamalu TN. Protein quality and toxicity of full-fat neem (Azadirachta indica A. JUSS) seed kernel. Arch Zootec 2006; 55(209):51-62.

13. Onyimonyi $A E$, Olabode, A, Okeke GC. Performance and economic characteristics of broilers fed varying dietary levels of neem leaf meal (Azadirachta indica). Int J Poult Sci 2009; 8(3):256-259.

14. Bonsu FRK, Kagya-Agyemang JK, Kwenin WKJ, Zanu HK. Medicinal Response of broiler chickens to diets containing neem (Azadirachta indica) leaf meal, haematology and meat sensory analysis. World Appl Sci J 2012; 19(6):800-805.

15. Iheukwumere FC, Ndubisi EC Etusiim PE. The use of different sources of protein on the growth and reproduction of pigs. Pak J Nutr 2008; 7(4):590-593.

16. Fasuyi AO, Aletor VA. Protein Replacement Value of cassava (Manihot esculenta, Crantz) leaf protein concentrate (CLPC) in broiler starter: effect on performance, muscle growth, haematology and serum metabolites. Int J Poult Sci 2005; 4(5):339-349.

17. Cortinas L, Villaverde C, Galobart J, Baucells MD, Codony R, Barroeta AC. Fatty Acid Content in Chicken Thigh and Breast as Affected by Dietary Polyunsaturation Level. Poult Sci 2004; 83(7):1155-1164.

18. Martínez Y, Valdivié M, Martínez O, Estarrón M, Córdova J. Utilización de la semilla de calabaza (Cucurbita moschata) en dietas para pollos de ceba. Rev Cubana Cienc Agríc 2010; 44(4):393-398.

19. Aroche GR, Rodríguez BR, Valdivié NM, Martínez, AY. Semilla de calabaza en dieta para pollos de ceba. Rev Prod Anim 2011; 23(2):103-108.

20. Salazar-Vega MI, Rosado-Rubio JG, Chel-Guerrero LA, Betancur-Ancona DA, Castellanos-Ruelas AF. Composición en ácido graso alfa linolénico $\left(w_{3}\right)$ en huevo y carne de aves empleando chia (Salvia hispánica L.) en el alimento. Interciencia 2009; 34(3):209-213. 